Northwestern University School of Law Northwestern University School of Law Scholarly Commons

Faculty Working Papers

2012

\title{
Execution in Virginia, 1859: The Trials of Green and Copeland
}

Steven Lubet

Northwestern University School of Law, slubet@law.northwestern.edu

\section{Repository Citation}

Lubet, Steven, "Execution in Virginia, 1859: The Trials of Green and Copeland" (2012). Faculty Working Papers. Paper 209.

http://scholarlycommons.law.northwestern.edu/facultyworkingpapers/209 
EXECUTION IN VIRGINIA, 1859:

THE TRIALS OF GREEN AND COPELAND

Steven Lubet ${ }^{1}$

On Sunday night, Oct. 16, 1859, John Brown and a company of 18 men entered the sleeping town of Harpers Ferry, Va., where they began an assault on slavery that would lead first to civil war and eventually to emancipation. ${ }^{2}$ They quickly took control of the United States arsenal, located in the heart of town, but shots were fired in the encounter, killing a black railroad worker and alerting the citizenry that a raid was under way. By mid-morning the following day, Brown and his men were surrounded by local militia whose constant fire killed many of the raiders. For a short while, however, there was a standoff. Brown's men were protected by the thick armory walls, and the militia members were too disorganized - and in some cases too drunk - to mount an effective assault on the insurrectionists' stronghold.

Late Monday, Oct. 17, a detachment of federal Marines arrived under the command of Robert E. Lee, and Brown's fate was sealed. At dawn on Tuesday morning, only five of Brown's men remained standing - several had fled and the others were dead or gravely wounded. When Brown refused a demand to surrender, a squadron of Lee's troops stormed the armory. Brown was taken alive and six other survivors were eventually captured as well.

One of the imprisoned raiders was John Copeland, a free black man from Oberlin, Ohio. Described in the press as a "bright mulatto," Copeland had been a highly visible leader of the Oberlin slave rescue the previous fall. Along with 36 others, he had been indicted by a federal grand jury for violating the Fugitive Slave Act, but he successfully evaded arrest, and he was thus already a fugitive himself when he arrived in Virginia to join Brown's army. ${ }^{3}$ Another captive was Shields

\footnotetext{
${ }^{1}$ Williams Memorial Professor of Law, Northwestern University. Parts of this essay are adapted from Steven Lubet, John Brown's Spy: The Adventurous Life and Tragic Confession of John E. Cook (Yale University Press, 2012).

${ }^{2}$ The town is now located in West Virginia. In 1859, it was known as Harper's Ferry, but the apostrophe was later removed in an early twentieth century postal reform. Other than in direct quotations, I have used the modern orthography throughout this essay.

${ }^{3}$ Regarding Copeland's background, see William Bigglestone, They Stopped in Oberlin: Black Residents and Visitors of the Nineteenth Century, pp. 50-52. The patronizing description of Copeland was made in multiple newspapers articles, including "A Confession," Richmond Enquirer, November 1, 1859; "Examination of the Conspirators," New York Tribune, October 29, 1859;" Fifth Day," New York Tribune, November 5, 1859; "John Brown's Invasion, "New York Tribune, November 12, 1859. For details of the Oberlin Slave Rescue, including John Copeland's involvement, see Steven Lubet, Fugitive Justice: Runaways, Rescuers, and Slavery on Trial, pp.229-47.
} 
Green, a fugitive slave from North Carolina. Green had been introduced to Brown by Frederick Douglass, the famous black abolitionist. Douglass himself had refused to join Brown's expedition to Virginia - believing that Brown would fall into a "perfect steel-trap" - but Green had readily agreed. As Douglass phrased it, Green was determined to "go down wid de old man."4

Although it had taken federal troops to quell Brown's rebellion, all of the captives, including Green and Copeland, were turned over to the Commonwealth of Virginia for prosecution. The Virginia authorities were naturally outraged at Brown, but Gov. Henry Wise nonetheless insisted that he be treated with the sort of grudging respect that is typically afforded a defeated commander. At the beginning of Brown's lengthy interrogation, for example, Wise admonished his prisoner that "he did not desire to hear anything from him that he did not willingly .. f feel disposed to communicate." Wise later praised Brown as "a man of clear head, of courage, fortitude and simple ingenuousness [who] inspired me with trust in his integrity, as a man of truth." ${ }^{\circ}$ As we will see, no such respect, grudging or otherwise, was shown to the black prisoners, who were treated far more roughly from beginning to end.

Following Brown's interrogation, all of the prisoners were taken to nearby Charles Town, where they were soon indicted on four capital counts by a unanimous grand jury. $^{7}$ Rendered in the baroque language of antebellum law, counts two and three charged murder (both direct and "aiding and abetting"), and count four alleged a conspiracy to induce slaves "to make insurrection against their masters and owners, and against the government, and the constitution and laws of the Commonwealth of Virginia."

\footnotetext{
4 Douglass, Frederick, "John Brown, speech delivered at Storer College, Harper's Ferry, West Virginia, May 30, 1881, in Foner, Philip, and Yuval Taylor, eds. Frederick Douglass: Selected Speeches and Writings at 633; Stauffer, John. The Black Hearts of Men: Radical Abolitionists and the Transformation of Race at 259.

5 Andrew Hunter testimony, Select Committee of the Senate Appointed to Inquire into the Late Invasion and Seizure of the Public Property at Harper's Ferry. 36th Cong. Report (1st sess., 1860)at 60. Regarding the inadmissibility of involuntary confessions in the pre-Miranda era, see Henry Smith, Henry. "The Modern Privilege: Its Nineteenth Century Origins." In The Privilege against Self-Incrimination, ed. R. H. Helmholz, 145-80.

${ }^{6}$ McGinty, John Brown's Trial at 68; "Speech of Governor Wise," Richmond Enquirer, October 25, 1859.

${ }^{7}$ Charles Town was then Charlestown but, as with Harper's Ferry, I have used the contemporary name other than in direct quotes.
} 
The heart of the indictment, however, was expressed in Count One, which charged that the prisoners had committed treason against the Commonwealth of Virginia by conspiring

... together with divers other evil minded and traitorous persons to the jurors unknown, not having the fear of God before their eyes, but being moved and seduced by the false and malignant counsels of other evil and traitorous persons, and the instigations of the Devil.

According to the indictment, Brown and his men had committed treason not only by plotting to "make rebellion and levy war" against the Commonwealth, but also by attempting to institute "a government separate from and hostile to the existing government" of Virginia and, in the language of the state treason statute, professing "allegiance and fidelity to said usurped government."

Fewer than two years later, virtually all of the officials in the Charles Town trial, including the prosecutors, the judge, and the governor, would themselves swear allegiance to the Confederate States of America - an actual "usurped government" if there ever was one - but they were never known afterward to have appreciated that particular irony. In any case, those events were still unforeseen in 1859 and, for the time being only Brown and his comrades faced hanging for treason.

The treason count raised profound questions of jurisdiction. Treason, at its core, involved the betrayal of allegiance to one's sovereign, and yet neither Brown nor Copeland, nor any of the other defendants, had ever been a citizen of Virginia (or even a resident) of Virginia, and the raid itself had occurred almost entirely on federal property. ${ }^{9}$ There would be evidentiary problems as well. While murder and incitement were straightforward crimes that would be relatively easy to prove, treason required the testimony of at least two witnesses to every overt act by each defendant. In addition to those obvious legal obstacles, the treason count was also

\footnotetext{
${ }^{8}$ Indictment of John Brown, et al, October 26, 1859. (John Brown Papers, Circuit Court of Jefferson County). The initial indictment was against John Brown, John Copeland, Shields Green, Aaron Stevens, and Edwin Coppoc, all of whom were taken prisoner in the immediate aftermath of the raid. Two other raiders - John Cook and Albert Hazlett - initially escaped, only to be captured in the following weeks and taken to Charles Town. Cook and Hazlett were also indicted on similar charges.

${ }^{9}$ Another defendant, John Cook, had lived in Virginia for over a year, serving as Brown's spy. Cook, however, had not yet been captured when the first indictment was issued.
} 
superfluous from the perspective of punishment, given that the murder and servile incitement counts all carried the death penalty.

Nonetheless, Virginia's Gov. Henry Wise had decided to use the prosecution to assail the entire abolitionist movement, and he saw the treason count - which was drafted by his personal lawyer, Andrew Hunter, who would also lead the Harper's Ferry prosecutions - as the ideal vehicle for charging that sanctimonious northerners, including prominent ministers and political figures, had engaged in a broad ranging conspiracy to make war against the Commonwealth of Virginia. Not only would Gov. Wise make his case against the votaries of abolitionism, but he would also assert Virginia's primacy over a federal government that had, in his eyes, failed for many years to take sufficient measures for the protection and expansion of slavery. There was one further complication: under Virginia law, clemency for treason (unlike all other crimes) required the approval of the legislature, and could not be granted by the governor alone. That limitation on gubernatorial authority, however, did not appear to trouble Gov. Wise who, in the immediate aftermath of the raid, had scant interest in pardoning any of the prisoners. The treason charge would thus become a major issue in the trials of John Brown, Shields Green, and John Copeland.

John Brown was the first of the insurgents to face trial. Almost from the moment he got to Charles Town, Brown had attempted to have his case postponed until sympathetic lawyers could arrive from the north, but Judge Richard Parker denied every request for delay. Instead, the court appointed two local lawyers - Lawson Botts and Thomas Green - to represent the defendant, and he insisted that Brown's trial begin post-haste. Brown protested, but to no avail. The first witness against him was called on Thursday, October 27, only nine days after the raid had collapsed.

Lawson Botts and Thomas Green were prominent members of the Charles Town bar. Both slaveholders themselves, they no sympathy for John Brown, and little reason to want to see him acquitted. Indeed, Green was the mayor of Charles Town, charged with protecting public safety, and Botts had actually been "in the 
thick of events at Harper's Ferry" as a member of one of the militia companies that had first surrounded the armory. ${ }^{10}$

Despite their personal interests and allegiances, Botts and Green were deeply committed professionals who did their best to represent John Brown. Of course, there was never any possibility that they would defend either his ideals or his actions, all of which they found abhorrent. Nor would they even hint that there was any justification for Brown's campaign to free Virginia's slaves. But within the confines of their own principles, Botts and Green spared no effort on Brown's behalf. They vigorously cross examined prosecution witnesses and, at Brown's request, subpoenaed witnesses to testify for the defense. More controversially, they obtained affidavits and other evidence showing that "insanity is hereditary in [Brown's] family." That was an incisive move in strictly legal terms, as an insanity plea was Brown's only hope - slight as it was - of avoiding execution, but the defendant naturally saw things differently. Brown refused to "put in the plea of insanity," and he objected to his lawyers' efforts to raise such "a miserable artifice and pretext." He viewed the entire strategy with "contempt," and he rejected "any attempt to interfere in my behalf on that score." 11 That closed the door on the issue, and Botts and Green soon moved to withdraw over continuing tactical disagreements with their client.

Fortunately, legal reinforcements arrived just as the local lawyers were quitting the case. Brown's northern friends had retained two experienced attorneys - Hiram Griswold and Samuel Chilton -who managed to reach Charles Town for the closing days of the trial. Hiram Griswold, of Cleveland, was a prominent member of Ohio's extensive anti-slavery bar, and he was eager to defend Brown as a matter of principle. Samuel Chilton was a lawyer of an entirely different stripe. Born and raised in Virginia, he was closely tied to most of the prominent families of Jefferson County, Jefferson County, although he now lived and practiced in Washington, D.C. Chilton disdained abolitionism, and he accepted the case only after Brown's supporters promised him the huge fee of $\$ 1000 .{ }^{12}$

Griswold and Chilton ably defended their client, calling witnesses on his behalf and presenting spirited closing arguments. Their defense, however, rested entirely on what we would now call technicalities. Griswold argued forcefully that

\footnotetext{
${ }^{10}$ Brian McGinty, John Brown's Trial at 101.

11 "Our Charlestown Despatch," New York Herald, October 28, 1859.

${ }^{12}$ John Lawson, American State Trials, vol. 6 at 766. McGinty, JB's Trial at 183.
} 
Brown could not be convicted of treason because he had never been a citizen, or even a resident, of Virginia. Taking good advantage of his distinctive southern accent, Chilton added that the murders had all been committed by others, and there was no direct proof that Brown himself had killed anybody. Chilton attempted to shift some of the blame to the other indicted prisoners - including Shields Green and John Copeland, whom he did not represent - while arguing that Brown's own acts had been committed without legal malice. ${ }^{13}$ While admitting that Brown's goal had been to free the slaves, neither Griswold nor Chilton questioned the legality, much less the morality, of slavery, which they thought would diminish the vanishingly small chance of saving their client's life.

Judge Parker committed the case to the jury in the early afternoon of Monday, October 31, although the outcome was recognized by observers as "a mere matter of form." ${ }^{\text {"14 }}$ The jurors deliberated for less than an hour before returning to court with their verdict: "Guilty of treason, and conspiring and advising with slaves and others to rebel, and murder in the first degree." 15

Brown had been compelled to endure his trial in near silence. Virginia adhered to the so-called "interested party" rule - as did every state in 1859 - which prohibited a criminal defendant from testifying in his own behalf. The rule was thought to be necessary to avoid the temptation to perjury, but it also prevented defendants such as Brown from appealing directly to the jury or to the public. That would change when Brown came before the court for sentencing.

Judge Parker ordered Brown to stand before the bench on Wednesday morning, November 2, while the clerk read the obligatory question. Did the defendant have "anything to say why sentence should not be pronounced upon him?" Eloquently and defiantly, Brown seized the moment:

In the first place, I deny everything but what I have all along admitted, of a design on my part to free slaves ....

This Court acknowledges, too, as I suppose, the validity of the law of God . . . which teaches me that all things whatsoever I would that men should do to

\footnotetext{
${ }^{13}$ Lawson, American State Trials, vol. 6 at 778-99.

14 Joseph Barr, The Annals of Harper's Ferry (1872) at 44.

${ }^{15}$ Lawson, American State Trials, vol. 6 at 799-800.
} 
me, I should do even so to them. It teaches me further to remember them that are in bonds, as bound with them. I endeavored to act upon that instruction ....

I believe that to have interfered as I have done, as I have always freely admitted I have done, in behalf of His despised poor, I did no wrong, but right. Now, if it is deemed necessary that I should forfeit my life for the furtherance of the ends of justice, and mingle my blood further with the blood of my children and with the blood of millions in this slave country whose rights are disregarded by wicked, cruel and unjust enactments, I say let it be done. ${ }^{16}$

Needless to say, Brown's oratory had no effect on Judge Parker, who simply remarked "that no reasonable doubt could exist of the guilt of the prisoner." $\mathrm{He}$ sentenced Brown to be hanged in public on Friday, December 2, 1859.

Journalists in the courtroom transcribed Brown's remarkable speech, and it was soon published in newspapers across the country. Brown's eloquent condemnation of slavery struck a deep chord in the North, "unleashing powerful imagery that would vastly deepen the meanings of his puny act of physical rebellion." Even abolitionists who had initially criticized or condemned the Harper's Ferry raid, soon found themselves praising Brown's courage and dedication, while denouncing his captors. "John Brown has twice as much right to hang Governor Wise as Governor Wise has to hang him," said Wendell Phillips, and he was far from alone in his sentiment. ${ }^{17}$

To the eventual dismay of his southern prosecutors, it was Brown who had seized control of the courtroom by reversing their roles and placing slavery itself on trial. In less than half an hour, Brown had transformed himself from a murderer to a martyr who would, in Ralph Waldo Emerson's words, "make the gallows glorious as the cross." ${ }^{, 18}$ It was a remarkable victory for the old abolitionist, in

\footnotetext{
${ }^{16}$ Lawson, American State Trials, vol. 6 at 801.

${ }^{17}$ Michael Fellman, In the Name of God and Country: Reconsidering Terrorism in American History at 40 . Wendell Phillips, Speeches, Lectures and Letters at 272.

${ }^{18}$ David Reynolds, John Brown, Abolitionist: The Man Who Killed Slavery, Sparked the Civil War, and Seeded Civil Rigthts at 357, 367.
} 
which he had gotten no help from his lawyers, who did their best to keep the explosive issue of slavery out of the trial.

$$
* * *
$$

John Brown's conviction and sentencing did not end the proceedings in Charles Town. There were six other defendants who had to face the bench, including Shields Green and John Copeland.

Both Green and Copeland had been questioned following their capture. In Copeland's case, the interrogation was especially severe. Among the prisoners, only Copeland had been at all well known before Brown's raid. As a leader of the Oberlin fugitive slave rescue, he was notorious in Ohio, and his status as an indicted fugitive therefore attracted the immediate attention of United States Marshal Mathew Johnson in Cleveland. Within days of his arrival in Charles Town, Copeland was confronted in his cell by Marshal Johnson, who was accompanied by Marshal Jefferson Martin of Virginia.

Marshal Johnson was a staunchly partisan, pro-slavery Democrat who had been responsible for rigging the jury in the trials of the Oberlin rescuers. Having been frustrated by Copeland's escape from Ohio, Johnson jumped at the opportunity to get his hands on the fugitive, intending to "to ferret out testimony implicating the other parties" to Brown's raid. Johnson was especially interested in gathering evidence against Republican Congressman Joshua Giddings, who was the bête noir of Ohio Democrats. In sharp contrast to Brown's courtly treatment by Governor Wise, Marshall Johnson's techniques were relentless, and Copeland eventually buckled under the pressure. The tactics had been so harsh, however, that they were condemned even by other pro-slavery Democrats. The Cleveland Daily Herald, for example, called Johnson's conduct "disreputable," and charged that Copeland's eventual statement had been shamefully "wormed out of a negro scared almost to death at the prospect of the gallows." ${ }^{19}$

\footnotetext{
19“"U.S. Marshal Johnson and His Negro Confession," Daily Cleveland Herald, November 5, 1859; "The Confession of the Negro Insurgent Copeland," Cleveland National Democrat, October 31, 1859.
} 
Proud of his work, and disdainful of any criticism, Johnson proudly informed the press that he had successfully extracted a full confession from the prisoner. $^{20}$ In reality, Copeland provided only limited information, none of which could be especially helpful in the prosecution of Giddings or others. He admitted that he had been recruited by Brown (which was no surprise to anyone) and he mentioned the involvement of several other raiders who were already dead, while insisting that his only intention had been "running off slaves." He told Johnson that two prominent Oberlin Republicans, the brothers Ralph and Samuel Plumb, had given him $\$ 15$ for expenses, and added cryptically that other unnamed persons in Cleveland had also given him "money to join John Brown."21 Notably missing from the confession, however, was any mention of Boston abolitionists, and even the Plumbs' involvement appeared to be slight and indirect. Ohio's Marshal Johnson might have gotten something he wanted out of Copeland, but Virginia's Gov. Wise was disappointed to say the least.

Shields Green was also interrogated, but no record was made of his responses. Robert E. Lee informed his superiors in Washington, D.C., that he had obtained "statements of those now in custody," but his official report provided no further details. ${ }^{22}$ There is no doubt, however, that Green resisted providing the

\footnotetext{
20"Harper's Ferry Insurgents," Richmond Enquirer, November 1, 1859; "John Brown's Invasion," New York Tribune, October 29, 1859; "John Brown's Invasion," New York Tribune, November 5, 1859; "John Brown's Invasion," New York Tribune, November 12, 1859. According to the journalist and illustrator David Hunter Strother, Copeland was overwhelmed with fear and cowered before his interrogators. Historian Benjamin Quarles, however, discounts Strother's observation as the predictable report of a typical antebellum racist. Benjamin Quarles, Allies for Freedom: Blacks and John Brown at 134. Copeland's fellow Oberliners believed that reports of his fearful confession were slanders spread "by those who never dreamed of nobleness in a negro. "A Monument," AngloAfrican, January 14, 1860. Prosecutor Andrew Hunter later claimed that he had also obtained a confession from Copeland, but no evidence of it was offered at trial. Andrew Hunter, "John Brown's Raid," Publications of the Southern History Association, July 1897, at 188.

${ }^{21}$ Lawson, American State Trials, vol. 6 at 811. According to another version of the confession, Copeland also implicated Charles Langston, one of the Oberlin rescuers and a leading black abolitionist in Ohio. David Hunter Strother, "Copeland's Confession;" Harper's Weekly, November 12, 1859; "The Confession of the Negro Insurgent Copeland," Cleveland National Democrat, October 31, 1859; "U.S. Marshal Johnson and His Negro Confession," Daily Cleveland Herald, November 5, 1859.

22 “Col. R.E. Lee's Report to Adjutant General," October 19, 1859, Wise Papers, Library of Virginia; also published in Virginia Magazine of History and Biography (July 1902) at 24. "A.H. List of Insurgents" (undated 1859), Wise Executive Papers, Library of Congress; also printed in Virginia Magazine of History and Biography (January 1902) at 274-75. See also, Calendar of Virginia State Papers and Other Manuscripts, January 1, 1836 to April 15, 1869, Vol. 11 at 349. See M. Johnson to Andrew Hunter, November 15, 1859, Wise Papers, Library of Virginia, also printed in Virginia Magazine of History and Biography (January 1902) at 276-77.
} 
details of his recruitment to the abolitionist army, and that he never mentioned having been introduced to Brown by Frederick Douglass. Any implication of Douglass would have been a bombshell, certain to have been trumpeted by the Virginia authorities and reported widely in the press. Instead, it is evident that Green protected his friend and, in fact, Douglass's meeting with Brown remained unknown until years later when Douglass revealed it himself.

Whatever the substance of Green's actual statement, it would play no role in the trials that followed. Copeland's confession was a different matter.

$* * *$

The two Virginia attorneys appointed for Brown had also accepted the representation of John Copeland and Shields Green, although it appears that they never met with their black clients. In any event, they evidently ceased even nominal representation of Copeland and Green when they withdrew from Brown's case. By that time, however, additional attorneys had arrived from the North, including the ardently abolitionist George Sennott, of Boston, who quickly filed his appearance for Copeland and Shields.

Sennott was a Rabelaisian figure, whose large waistline, extravagant personality and prodigious appetites caused much spiteful laughter in Charles Town. The local newspapers could not find enough insulting things to say about him. "George Sennott has come to us upon a mission of great bigness, and his size, so far as latitude is concerned, shows him fully up to the immortal standard of envoys extraordinary," snickered one reporter. "When he is out of Boston," cackled another journalist, "we presume lager beer has an opportunity to accumulate." In fact Sennott was an excellent attorney. He was an antislavery Democrat - a combination unusual in the North and unheard of in the South - and the contrast between his moral convictions and his political affiliation might have contributed to the derision he had to endure. One observer called him "the celebrated Damphool," although that was before anyone saw him in action. ${ }^{23}$

Unlike the apologetic Samuel Chilton, or the circumspect Hiram Griswold, Sennott did not hesitate to speak up for his clients' principles. He boldly said that

23 "The Court and Those Who Appear in It," New York Tribune November 12, 1859. 
it was his honor to defend Green and Copeland, and he declared in court that "the system of Slavery is illogical and absurd." That did not endear him to the public in Charles Town, where he was accused of "making an Abolition harangue" upon his first appearance in court. Eventually, however, he would earn grudging admiration for his legal skills. One Charles Town newspaper later reported with surprise that Sennott was "doing his damndest" for Shields Green - who was condescendingly described as "a regular out-and-out tar-colored darkey" - and that there was actually a chance that Sennott might secure an acquittal. ${ }^{24}$

Green's case was called first, and the evidence against was overwhelming. The chief witness against him was the plantation master Lewis Washington, a great-nephew of George Washington who had been kidnapped by Brown's men and held as a hostage. Washington testified that Green had been in charge of guarding the hostages, and that he had been armed with a rifle, a revolver, and a butcher knife. Washington also claimed to have seen Green firing at the surrounding militia, but that was not his worst offense. Far more heinous, in Washington's eyes, was Green's “impudent manner." Although he had been born in slavery, Green had a self-confident bearing that led his friends to affectionately call him "Emperor." Washington, in contrast, was accustomed to enforced deference from black men, and he therefore saw only effrontery where others recognized dignity. He was especially offended that Green had dared to give orders to a white man.

Washington also considered Green a coward. When the final attack was made on the engine house, according to Washington, Green threw away his weapons and attempted to act as though he was one of the local slaves. There was nothing really cowardly about trying to live to fight another day, and in fact, Green showed considerable courage during his interrogation. Despite Washington's condescending opinion, the Emperor was noble enough to protect his friends.

George Sennott first showed off his flashy legal skills in defense of Green. "His struggle with the prosecution was a sort of guerrilla warfare [in which] he attacked the indictment on all points." Most effective was his motion to dismiss the treason charge "on the strength of the Dred Scott decision, which deprives

\footnotetext{
${ }^{24}$ “The Court and Those Who Appear in It," New York Tribune November 12, 1859 (capitalization in original). The local newspaper was the Spirit of Jefferson, which was quoted at length in the Tribune.
} 
negroes of citizenship, and consequently of their treasonable capabilities." In Dred Scott, decided only two years earlier, the United States Supreme Court had infamously observed that a black man had "no rights which the white man was bound to respect." 25 It was nearly impossible for an abolitionist to find any redeeming virtue in the Dred Scott case, But Sennott had sensed a way to turn it to his clients' advantage.

Sennott's argument was both ironic and incisive, and he used it to point out the hypocrisy of slavery itself. A treason conviction had to rest on a betrayal of allegiance, but Chief Justice Taney had ruled that black men could not be citizens of a state, which negated any possible duty of loyalty to Virginia. Thus, Sennott argued, the first count of the indictment had to be dismissed. The spectators gaped in 'amazement at the utterance of 'Abolition sentiments' in a Virginia Court of justice," but Judge Parker appeared to realize that he had been backed into a corner. The prosecutor objected loudly to the motion, but the logic of Sennott's position was undeniable and the treason charge was dismissed by the court. ${ }^{26}$ Sennott's other arguments did not fare well. He sought the dismissal of the other counts on various technical grounds - including a farsighted challenge to the composition of the jury that was over a century ahead of its time - but Parker denied every motion. Then, after only the briefest deliberation, the jury returned verdicts of guilty on the charges of murder and conspiracy.

John Copeland's trial followed immediately after Green's. Sennott opened Copeland's defense by again moving for the dismissal of the treason count. This time the prosecution agreed to abandon the charge, while insisting that Copeland's confession was sufficient to find him guilty of both murder and inciting a servile rebellion. Sennott argued that the confession was inadmissible, as "it had been made under influence as well as threats." While Sennott's factual assertion was undoubtedly true - outside of Virginia, even bigots recognized that Copeland had been coerced -- Judge Parker overruled the objection on legal grounds. Antebellum Virginia law simply could not accept the concept that black prisoners were entitled to remain silent when questioned by white authorities. The imaginative Sennott, however, had another argument up his sleeve. In that case, he

\footnotetext{
${ }^{25}$ Dred Scott v. Sandford, 60 U.S. 393 (1857)

26 "The Court and Those Who Appear in It," New York Tribune November 12, 1859 (capitalizations in original).
} 
contended, Copeland's confession had to be taken as a whole. The defendant had admitted only to attempting to "run off slaves," which amounted to the crime of slave stealing, as opposed to murder, conspiracy and rebellion. Slave stealing, however, had not been charged in the indictment, and the prosecution "could not be allowed now to contradict their own story."

For the first time in any of the Harper's Ferry trials, Parker appeared to be moved by a highly technical legal argument. The judge complimented Sennott for his persuasiveness, and visibly hesitated before ruling on the defense motion. Realizing that his entire case was in trouble, the prosecutor sputtered that he had proved a common purpose among the raiders that defense counsel's "ingenious pleading" could not evade. But still Parker hesitated, creating a palpable stir among the spectators. Finally, the court ruled that mere "evidence of a conspiracy to run off slaves did not and would not support" the indictment, but that the jury could decide whether there had been sufficient proof of a "common design [of rebellion] chargeable upon all the conspirators." 27 With that fateful instruction, the jury retired and, for the first time in any of the proceedings, a spirited discussion could be heard in the jury room. Sennott's argument had given the jurors some pause, but they eventually returned a verdict of guilty on every count save treason. Judge Parker set sentencing for the following week.

Court convened at noon on Thursday, November 10, for the sentencing of four prisoners, two black and two white. In addition to Copeland and Green, John Cook and Edwin Coppoc had also been convicted of murder and conspiracy in the preceding week. ${ }^{28}$ Cook was accompanied by a phalanx of friends and family including his brother-in-law, who was the sitting governor of Indiana - as well as several prominent attorneys. Coppoc, a naïve Quaker from Iowa, also had relatives present, although none as influential as Cook's. The two black men were alone, their attorney having returned to Boston some days earlier.

\footnotetext{
27 "The Trials of the Accused," New York Tribune, November 12, 1859.

${ }^{28}$ Coppoc had also been convicted of treason against Virginia, while Cook had been acquitted of that charge. Two other prisoners - Aaron Stevens and Albert Hazlett - had not yet faced trial; they would be convicted and executed the following spring.
} 
The court clerk directed the prisoners to stand. In language required by the Virginia statutes, he asked if any of them "had anything to say why sentence according to the terms of the verdict, should not now be passed." 29

Each of the white prisoners spoke emotionally in a last ditch effort save his own life. Both men said they regretted joining the insurrection, claiming they had been deceived by Brown into thinking that Virginia's slaves were longing for freedom. John Cook was especially voluble, speaking at considerable length and with great passion.

According to several newspapers, "the negroes declined saying anything" at the sentencing hearing. In another account, "Shields Green said he had nothing to say, whilst Copeland remained mum." ${ }^{30}$ The implication was that the court offered Green and Copeland an opportunity to speak on their own behalf, and they remained silent out of either fear or hopelessness. But those reports may not have been quite accurate.

John Copeland, having been raised in the uniquely integrated community of Oberlin, was an exceptionally outspoken and adamant opponent of slavery. Unlike southern slaves and free blacks, he had not grown up in an atmosphere of intimidation and illiteracy. Having attended Oberlin College, he was well educated and expressive, and he was not reluctant to speak his mind. It would have been uncharacteristic for Copeland to have remained mute if he had been offered an opportunity to address the court. It is therefore entirely possible, or even likely, that Judge Parker, himself a slave owner, did not allow the black prisoners any meaningful occasion to speak at sentencing, although he may have momentarily glanced in their direction following the allocutions of Coppoc and Cook.

It is easy to understand how a perfunctory nod to Green and Copeland could have been reported as though the court had given them an actual opportunity to speak. Most journalists, especially those from the South, showed markedly little interest in Green and Copeland throughout the course of the Harper's Ferry trials.

\footnotetext{
29 "Sentence of Prisoners," Virginia Free Press, November 17, 1859;"Close of the Trials," Baltimore American, November 12, 1859.

30 "Sentence of Prisoners," Virginia Free Press, November 17, 1859; "Close of the Trials," Baltimore American, November 12, 1859; "The Sentence of the Harper's Ferry Insurgents," Dawson's Daily Times, November 19, 1859; "The Trials at Charlestown," New York Tribune, November 19, 1859.
} 
Most of the coverage focused on Brown, of course, but there were also many stories about the other white men. In contrast, almost none of the local or national newspapers devoted significant space to Green and Copeland - the only exception having been stories about Copeland's confession, which implicated white men typically limiting their reports to one or two perfunctory paragraphs. And no reporter appears to have been particularly interested in Shields Green, other than to disparage him as appearing "so woe-begone that there was small room for his looking worse." 31

Judge Parker was "obviously laboring under much feeling" as he proceeded to pronounce sentence in regretful language that was obviously directed only to Cook and Coppoc. "In spite of your offences against our laws,' Parker said, "I cannot but feel deeply for you, and sincerely, most sincerely, do I sympathize with those friends and relations whose lives are bound up in yours." 32 But all sympathies aside, Parker had an obligation to fulfill. "To conclude this sad duty," he continued, "I now announce that the sentence of law is that you, and each one of you ... . be hanged by the neck until you be dead." The court set the execution date for Friday, December 16. The sheriff was ordered to hang the two black men "between the hours of eight in the forenoon and twelve noon," with the two white men to follow "in the afternoon of [the] same day." 33

Even in death, Virginia demanded strict segregation of the races. In what may have been the most unintentionally trenchant report of the day, the Virginia Free Press observed that "the negroes, Green and Copeland, made no response" when the court ruled that they were not fit to die alongside their white comrades. ${ }^{34}$

$* * *$

\footnotetext{
31"Our Charlestown Desptach," New York Herald, November 10, 1859.

32 "Sentence of the Harper's Ferry Insurgents," Dawson's Daily Times, November 19, 1859. "Sentence of the Prisoners," Virginia Free Press, November 17, 1859.

${ }^{33}$ "Close of the Trials," Baltimore American, November 12, 1859; "The Trials at Charlestown," New York Tribune, November 19, 1859. Death Warrants for John E. Cooke, Shields Green, and John Copeland, November 10, 1859 (John Brown Papers, Circuit Court of Jefferson County). There was also a death warrant for Edwin Coppoc, but it has not survived in the records of the court.

34“"Sentence of Prisoners," Virginia Free Press, November 17, 1859.
} 
Barely three weeks had passed since the collapse of Brown's raid, and the Virginia courts had sped through five trials and delivered five death sentences. But that was not the end of the legal maneuvering. Intensive efforts were immediately undertaken to secure pardons for the three white defendants. Brown's friends and sympathizers besieged Gov. Henry Wise with letters urging him to commute the death sentence, arguing either that Brown was insane, or alternatively that his martyrdom would only encourage further abolitionist violence. None of the entreaties, however, had the desired effect. Brown's treason conviction meant that the governor could not pardon him without the consent of the legislature, and Wise - who still hoped to obtain the Democratic presidential nomination in 1860 -- was not disposed to open the issue for widespread political debate. He wrote privately to the prosecutor that he did not intend to pardon Brown, and he leaked word to the Richmond Enquirer that Brown's fate "may be considered as sealed." 35

There was never any real chance that Brown would be spared the gallows, but the pardon efforts on behalf of Cook and Coppoc were more promising. Cook was from an influential family - with both wealth and political connections - and his attorneys secured a private audience with Gov. Wise, where they presented their case for executive clemency. Because Cook had been acquitted of treason, his fate was entirely in Wise's hands. The lawyers argued that Cook was a naive youth (although in fact, he was already thirty years old) who had been misled by the villainous John Brown. Wise, however, was unmoved, and he let it be known that no "unbiased mind" could possibly "desire the pardon of this man.",36

Coppoc's case was more complicated. Having been convicted of treason against Virginia, he could not be pardoned without the prior consent of the state legislature. Coppoc did, however, have the support of the Quaker communities in Ohio, Iowa, and elsewhere, which generated considerable sympathy in Virginia. At one point, a committee of the Virginia Senate actually recommended a pardon for Coppoc, but the full legislature rejected the proposal when it was discovered

\footnotetext{
${ }^{35}$ McGinty, John Brown's Trial at 241-48.

36“The Pardon of Cook," Richmond Enquirer, November 25, 1859.
} 
that he had written an inflammatory letter to John Brown's wife in which he referred to Virginians as "the enemy.",37

Shields Green and John Copeland had neither formidable friends nor influential communities to plead for their lives. Nonetheless, many free blacks of the north, powerless and disenfranchised as they were, did their best to aid the black prisoners. Most affecting was a letter sent to Gov. Wise by a "committee of colored persons" in Philadelphia, seeking reprieves for Green and Copeland. "We plead," they wrote, for "the intervention of your executive influence in behalf of these poor, miserably misguided men." Walking a delicate line, the Philadelphians acknowledged the guilt of Copeland and Green, while pointing out the mitigating circumstance of race:

Whatever may have been the impulse that moved them to this desperate act of self destruction, it must be remembered that they are of an identity of interest, complexion, and of national proscription with the men whose liberty they sought to secure.

All these things may have operated on their minds as an incentive, driving them into the ranks of Capt. Brown, [so] do they not present strong arguments in the extenuation of their guilt, and may they not justly claim the interposition of Executive clemency in their behalf?

It was inconceivable that any Virginian, much less Gov. Wise, would ever admit that black men had a valid reason to rebel, no matter how strong their "identity of interest" with unliberated slaves. Recognizing the hopelessness of their appeal for mercy, the Philadelphians thus made a much more modest request as well:

We therefore humbly ask that you will grant to us, in the event of their being hung, the bodies of Shields Green and John Copeland, to be transmitted to us for a respectable interment. ${ }^{38}$

For black men in Virginia, even the decency of burial evidently required the intervention of executive authority. Decades later, both Judge Richard Parker and

\footnotetext{
${ }^{37}$ Oswald Garrison Villard, John Brown, 1800-1859: A Biography Fifty Years After at 570; Galbreath, “Edwin Coppoc," Ohio History, October 1921 at 428

38 "Request to Governor Wise for the Bodies of the Colored Men," New York Tribune, December 17, 1859.
} 
lead prosecutor Andrew Hunter would write that they had favored a commutation of Copeland's death sentence - believing him to be the most "manly" and respectable of the prisoners - but that executive clemency was precluded by a treason conviction. Of course, Copeland had actually been cleared of treason by virtue of his status under the Dred Scott decision, and a clemency recommendation from either Parker or Hunter could have been entertained by Gov. Wise. Perhaps Parker and Hunter belatedly wished they had spoken up on Copeland's behalf, but in any case their protestations of sympathy were untrue. In the event, no Virginian advocated mercy for Green or Copeland. Gov. Wise, of course, was unmoved by the petition from Philadelphia - to which he never bothered to reply - and the death sentences were allowed to stand. ${ }^{39}$

\section{$* * *$}

John Brown was executed on Thursday, December 2, 1859. On the way to the gallows, he was allowed to visit briefly with his fellow prisoners. His first stop was in the cell of Green and Copeland, where he found the two black men manacled together. As befit a military leader, Brown greeted his comrades warmly, if sternly. He told "the two faithful colored men" to "stand up like men, and not betray their friends." He then handed them a quarter each, saying that "he had no more use for money." 40 Brown's gesture was probably more affectionate and less odd than it now seems. There was nothing more he could do for the two condemned men, and the present of even a small amount of money may have expressed his hope that they might be reprieved before their own execution date two weeks hence.

Brown's futile hopes aside, Green and Copeland's execution day arrived with no hint of mercy from Gov. Wise. Reveille sounded at dawn on Friday, December 16, and soon the streets of Charles Town were filled with soldiers, most of who had been on duty all night or "sleeping on their arms." The first executions would not be for several hours, but there were many preparations to be made. The scaffold had to be erected; the prisoners had to be readied; and security measures had to be employed. Country folk from the surrounding counties and strangers

\footnotetext{
${ }^{39}$ Hunter, Brown's Raid at 188; “The Trial of John Brown: Its Secret History, Revealed for the First Time by the Judge," St. Louis Globe-Democrat, April 8, 1886.

40"Brown's Interview with His Fellow Prisoners," New York Times, December 3, 1859; Franklin Sanborn, The Life and Letters of John Brown, Liberator of Kansas and Martyr of Virginia at 625.
} 
from as far as Baltimore began to arrive at first light, only to be stopped by nervous soldiers at the outskirts of town. Those who could not give a satisfactory "account of themselves or get some citizen to vouch for them" were taken to a guard house and confined until after the executions. Most of the travelers were allowed to proceed, but anyone who expected a good time would soon be disappointed. "The heavens were overcast, the air raw and bitter," and it appeared that an "equinoctial storm" was about to descend on the valley. The apprehensive public mood was in keeping with the threatening weather. ${ }^{41}$

We do not know how Shields Green spent his last hours, but John Copeland composed a moving letter to his family in Oberlin. "Dear parents, brothers and sisters," he wrote, "it is true that I am now in a few hours to start on a journey from which no traveler returns." He offered a prayer "that you, one and all, may prepare your souls to meet your God, that so, in the end, though we meet no more on earth, we shall meet in heaven, where we shall not be parted by the demands of the cruel and unjust monster Slavery.",42

A deputation of Charles Town clergy came to the jail, hoping to inspire expressions of remorse. They went first to the cell of Shields Green and John Copeland, who were scheduled to be hanged in the morning (with their white comrades following in the afternoon). As usual, most of the press paid little attention to the black prisoners, with the New York Tribune mentioning only that ministers led an impressive religious ceremony in their cell. The local Shepherdstown Register was somewhat more expansive, reporting that Shields Green wanted to "pray and prepare for another world," while John Copeland spoke out more forcefully. "If I am dying for freedom," he said, "I could not die in a better cause - I would rather die than be a slave." 43

Shortly after 10:30 that morning, Gen. William Taliaferro of the Virginia militia arrived at the jail, ready to escort Green and Copeland to the gallows. A contingent of about twenty-five troops formed a hollow square at the jailhouse

\footnotetext{
41"The Charlestown Executions," New York Tribune, December 17, 1859; “Consummation of the Harper's Ferry Tragedy," Cincinnati Gazette, December 16, 1859 (transcribed in Boyd Stutler Collection, West Virginia Memory Project); George Mauzy to Eugenia Burton, December 18, 1859 (capitalization original) (Boyd Stutler Collection, West Virginia Archive).

42 John Copeland to Dear Father, Mother, Brothers Henry, William and Freddy and Sisters Sarah and Mary, December 16, 1859 (Oberlin College Archive).

43 "Last Hours of Cook, Coppic, and Shields Green," Shepherdstown Register, December 24, 1859.
} 
door, as the jailor and county sheriff led the prisoners out of the building and down the steps. An open wagon holding two rough poplar coffins drew into the middle of the square, and Campbell helped the two prisoners take their seats on the caskets. With their arms pinioned, Green and Copeland appeared downcast, and "wore none of that calm and cheerful spirit evinced by Brown under similar circumstances." By 10:45, the cortege was underway, flanked by riflemen on either side as it passed through the crowded street. It took less than ten minutes to reach the hanging ground, where the two prisoners were led up the scaffold steps to the center of the platform. Copeland remained quiet, but Green is said to have trembled with fear and prayed out loud.

Following a minister's obligatory prayer, Copeland attempted to speak to the large crowd. Condemned men were routinely allowed a final address in the nineteenth century, and Copeland therefore expected to make one last statement about the injustices of slavery. But that common privilege was apparently denied to black men in Virginia. The hangman intervened, pulling hoods down around the heads of the prisoners and affixing ropes around their necks. The trap was drawn at a few minutes after eleven o'clock, and the two men were "launched into eternity." Green appeared to die instantly, his neck having been broken by the fall, but Copeland was slowly strangled and he "writhed in violent contortions for several minutes." 44

Green and Copeland were allowed to hang for half an hour, until they were cut down and pronounced dead by a physician. Gov. Wise had evidently denied the petition of the Philadelphia "committee of colored persons," and no plans had been made to send the bodies north for the requested respectable interment. In fact, it was expected that Green and Copeland would rest only briefly in their graves. A group of medical students from nearby Winchester attended the hanging, and it was understood that they did not intend to leave the dead men buried for long. ${ }^{45}$

\footnotetext{
${ }^{44}$ "Execution of Green and Copeland," Richmond Enquirer, December 20, 1859. Regarding the custom of the condemned prisoner's speech from the gallows, see Stuart Banner, The Death Penalty in American History at 24. 45 "Consummation of the Harper's Ferry Tragedy," Cincinnati Gazette, December 16, 1859 (transcribed in Stutler Collection); Richmond Enquirer, December 20, 1859. James Monroe, Oberlin Thursday Lectures, Addresses, and Essays at 170-71.
} 
After John Cook and Edwin Coppoc were executed later that day, their families had no difficulty securing their remains. Coppoc was put into a walnut casket, supplied by the local undertaker, to be sent to his mother in Iowa. Cook's family had provided an even more elegant coffin, replete with brass fittings, with instructions that it be shipped to his wealthy sister and brother-in-law in Brooklyn. Brown's corpse, too, had been shipped north at the request of his wife. Gov. Wise assured Mary Brown that the body would be "protected from all mutilation," and he instructed that it be delivered to her promptly in "a plain, decent coffin."

Shields Green had no known relatives to claim his body, but John Copeland's father made great efforts to obtain a decent burial for his son. In the weeks before the execution, the elder Copeland repeatedly wrote to Gov. Wise seeking permission to retrieve his son's body. Wise finally replied, only four days before the execution date. The Copelands could send a messenger to claim the corpse, but it had to be a white person. "You cannot come to this state yourself." With little time to spare, the Copelands, acting through a white friend, attempted to arrange for the body to be shipped to the custody of A.N. Beecher, the mayor of Oberlin. The appeal eventually found its way to Gen Taliaferro, who oversaw the execution. Taliaferro simply ignored request. With no one present to take custody of the corpses, he ordered them to be buried immediately on the hanging ground. ${ }^{47}$

With the tacit approval of the authorities, Green and Copeland were allowed to "remain in the ground but a few moments, before they were taken up and conveyed to Winchester for dissection" at the medical school. ${ }^{48}$ The dean of the medical school would later ask Wise for permission to place the skeletons on display in the college's anatomy museum, which was apparently necessary because legally available skeletons were scarce and none of the hospital's indigent patients were reliably close to death. Wise gave his assent, inasmuch as the bodies had not been "demanded by their proper relatives." 49

But John Copeland's "proper relatives" had never given up. On the day after the execution, Mr. and Mrs. Copeland sought the assistance of James Monroe,

\footnotetext{
${ }^{46}$ Tony Horwitz, Midnight Rising: John Brown and the Raid that Sparked the Civil War at 243.

${ }^{47}$ Quarles, Allies for Freedom at 140.

48 "Consummation of the Harper's Ferry Tragedy," Cincinnati Gazette, December 16, 1859 (transcribed in Stutler Collection); Richmond Enquirer, December 20, 1859. Monroe, Oberlin Lectures at 170-71.

${ }^{49}$ Quarles at 141.
} 
an Oberlin professor and a member of the Ohio state senate. News had by then reached Ohio that the bodies of the black prisoners had been turned over the medical school for dissection, and the Copelands implored Monroe to "go promptly to Winchester [to] endeavor to recover the body of their son." Although he was firmly opposed to slavery, the professor was at first reluctant to undertake such an expensive and potentially dangerous mission. He explained to the Copelands that it was probably too late, and that hostility in Virginia was likely to make the task impossible. Mrs. Copeland, however, "exhibited such intense suffering" that Monroe relented. ${ }^{50}$

Preparation for the journey was not simple. Monroe first procured a letter from attorney Hiram Griswold, who had represented Brown in the Charles Town trial, introducing him to Judge Richard Parker who, conveniently, happened to live in Winchester. He then obtained the telegram that Gov. Wise had sent the Copelands, allowing them to send a white messenger to retrieve their son's body. Mr. Copeland then executed an affidavit, appointing Monroe as his agent for the purpose of "receiving the body." All that was missing was money. The Copelands had none, and Monroe was a self-described "impecunious" academic. Fortunately, members of Oberlin's abolitionist community were able to raise $\$ 100$ - largely through door-to-door solicitations - which was sufficient to cover Monroe's expenses.

Monroe departed Oberlin by rail on Wednesday, December 19, finally reaching Winchester on late Friday evening. Although more than two months had passed since Brown's raid, northerners were still treated with suspicion in Virginia, and Monroe was interrogated by both railroad officials and fellow passengers. Still, he arrived in Winchester without incident (other than a lengthy delay due to snowfall in the Alleghenies), and he headed directly to the Taylor House for lodging.

At the hotel, Monroe was informed that he had to provide his name and address in the registration book, which was evidently open for inspection by a group of "rough and rather spirituous" looking young men who eyed the stranger in the lobby with barely concealed hostility. Monroe therefore hesitated to see

\footnotetext{
${ }^{50}$ Unless noted otherwise, the story of James Monroe's journey to Virginia is taken from his 1897 memoir, Oberlin Thursday Lectures, Addresses, and Essays at 158-84.
} 
"Oberlin written upon the pages of the register," fearful that mere mention of his famously abolitionist hometown "might produce a degree of excitement unfavorable to my object in visiting the place." Proceeding with well-justified caution, he therefore signed in as "James Monroe, Russia," substituting the name of Oberlin's surrounding township for the village itself. Sure enough, the local toughs immediately scrutinized the registration book, but they decided to leave the "Russian" visitor in peace.

Monroe's first stop the following day was at the home of Judge Richard Parker, where he presented his letter of introduction. Parker received Monroe with great courtesy, and expressed sincere sympathy for Copeland's "afflicted father and mother." The judge offered to arrange a meeting between Monroe and the medical school faculty, to be held that day following afternoon tea.

Prof. Monroe was no stranger to faculty meetings, and he was evidently quite persuasive in such a familiar milieu. The Winchester medical faculty "unanimously agreed that the body of Copeland should be . . . returned to the home of his parents," and the "college undertaker" volunteered to work through the night in order to prepare the corpse, now six days post mortem, so that the "sorrowful freight should be decently prepared for delivery at the express office the next morning. The only discouraging note was sounded by one of the medical school professors, who cautioned Monroe not to mention their meeting when he returned to his hotel. Already wary of disclosing his mission, Monroe assured the physician that he would keep mum, and he returned to the Taylor House quite satisfied that his mission would soon be successfully completed.

Monroe was therefore stunned when a committee of medical students arrived at the hotel early the next morning. Monroe was accustomed to deference from his own students, many of whom were seminarians, but this group was highly agitated and not very respectful. Their leader was a tall red-haired young man from Georgia who refused Monroe's invitation to sit down. Instead, he insisted on standing while delivering an ultimatum in a pronounced southern drawl:

Sah, this nigger that you are trying to get don't belong to the Faculty. He isn't theirs to give away. They had no right to promise him to you. He 
belongs to us students, sah .... [F]or the faculty to attempt to take him from us, is mo' 'an we can b'ar.

If the cadaver belonged to anyone - other than Copeland's parents - it could only have been the Commonwealth of Virginia, and Monroe was carrying unquestionable legal authorization from the governor to take the corpse to Ohio. The medical students, however, had no interest in legal niceties. Although aware that Monroe carried Gov. Wise's authorization "to come into this State and get this nigger," they denied the governor's "authority over the affairs of our college [and repudiated] any interference on his part." In case the implicit threat was not sufficiently clear, the students' leader warned Monroe,

You must see, sah, and the Faculty must see, that if you persist in trying to carry out the arrangement you have made, it will open the do' for all sorts of trouble .... Now, sah, that the facts are befo' you, we trust that we can go away with your assurance that you will abandon the enterprise on which you came to our town. Such an assurance is necessary to give quiet to our people.

To his great credit, Monroe did not give up. He sought out the assistance of a medical school professor, in the hope that he might still be able to claim Copeland's body. Although ostensibly willing to help, the professor informed Monroe that his quest had become "impractible." The students had already broken into the college dissecting room and removed the cadaver, hiding it "at some place in the country." Any further effort to recover the body would only lead to violence.

Shields Green's body, however, had been left behind, the students having realized that its custody and fate would not be contested. A member of the medical school faculty made a point of exhibiting the cadaver to Monroe, perhaps as proof that the faculty retained some slight control over their own institution. Monroe, however, saw only tragedy in Green's condition. He was especially moved by the dead raider's

... unclosed, wistful eyes staring wildly upward, as if seeking, in a better world, for some solution of the dark problems of horror and oppression so hard to be explained in this. 
Monroe prepared to depart Virginia that day, settling his hotel bill and also paying a considerable sum to the college mortician whose work had been interrupted by the unruly students. Due to the infrequent rail service in Winchester, it was necessary for him to travel by carriage to Martinsburg, where he could catch a train to Ohio. Just before he left, however, he was warned to stay out of sight in Martinsburg. There was going to be a militia review that day, including many of the troops who had attended Brown's execution. The town would therefore be filled with "many violent and half-drunken men . . whom it would be well for me to avoid."

\section{$* * *$}

Shields Green and John Copeland were dead and unburied, but they were not forgotten. Upon Monroe's return to Oberlin, a mass meeting was held - on Christmas Day, as it turned out - to commemorate the lives of Shields Green, John Copeland. Monroe addressed the rally, explaining to the crowd of over 3000 that his mission had been both a failure and a success. He had, of course, failed in his attempt to repatriate Copeland's body, but the community of Oberlin had succeeded in demonstrating a sense of duty to all of its citizens, regardless of color. Mr. and Mrs. Copeland also expressed gratitude to their neighbors, taking comfort in the knowledge that "every reasonable effort had been made in their own behalf, and in behalf of the memory of their son." In a moving eulogy, Oberlin Professor Henry Peck - one of the indicted Oberlin rescuers - praised John Copeland as a "firm, heroic, and Christlike champion" of his race, comparable to "the immortal John Brown." 51

The Winchester medical college was burned to the ground by the Union Army in May 1862. With it were destroyed whatever remained of the corpses of Shields Green and John Copeland. The school was never rebuilt.

In 1865, the town of Oberlin erected a memorial to Shields Green, John Copeland, and Lewis Sheridan Leary (another black Oberliner who joined John Brown and died in the fighting at Harper's Ferry). The inscription on the cenotaph reads, "These colored citizens of Oberlin, the heroic associates of the immortal

${ }^{51}$ Quarles at 142. "A Monument," Anglo-African, January 14, 1860. 
John Brown, gave their lives for the slave. Et nunc servitudo etiam mortua est, laus deo."

In fact, Green had never lived in Oberlin, but the sentiment was sincere and the honor well deserved. ${ }^{52}$ The Latin phrase means, "And now slavery is indeed dead, thanks be to God."

\footnotetext{
${ }^{52}$ Monroe erroneously believed that he had known Green in Oberlin. The mistake was discovered, but it was decided to leave Green's name on the cenotaph as a gesture of respect for his sacrifice, and as a representative of "every colored person in this land" who had resisted slavery. "We have not thought it right to withhold from such, nor indeed from any the privilege of sharing the honor with us." "A Monument," Anglo-African, January 14, 1860. There were two other black men among Brown's raiders: Osborne Anderson, who escaped to safety, and Dangerfield Newby, who was the first to die in the fighting. At one point the Oberliners considered including Newby's name on their monument, but it was ultimately decided to include only those who were thought to have some connection to Oberlin. J.M. Fitch to James Redpath, July 17, 1860 (Richard Hinton Collection, Kansas State Historical Society).
} 